\title{
Early Prenatal Diagnosis of Hurler's Syndrome with Termination of Pregnancy and Confirmatory Findings on the Fetus
}

\author{
M. d'A. CRAWFURD, M. F. DEAN, D. M. HUNT,* D. R. JOHNSON, \\ R. R. MACDONALD, H. MUIR, E. A. PAYLING WRIGHT, \\ and C. R. PAYLING WRIGHT $†$
}

Departments of Genetics and of Obstetrics and Gynaecology, University of Leeds; Departments of Animal Genetics and of Human Genetics, University College London; and The Kennedy Institute of Rheumatology, London

Summary. Type I mucopolysaccharidosis was diagnosed in a fetus by assay of the glycosaminoglycans of the amniotic liquor. Results are presented of biochemical and ultrastructural studies on the 18-week abortus. The evidence suggests that the liver is more severely affected than the central nervous system at this stage of gestation, and this finding agrees with the recent demonstration of the underlying enzyme defect of this disorder, with the corollary that many biochemical abnormalities previously noted in gargoylism must be pleiotropic effects of the mutant genotype.

Although the prenatal diagnosis of the mucopolysaccharidoses was first described by Fratantoni et al (1969), there still appears to be no wholly satisfactory single test which will allow these conditions to be recognized in the fetus both quickly and unequivocally. A number of methods have been proposed, and it has been suggested (Milunsky et al, 1970) that they should be used in parallel. In this paper we report a case where the diagnosis was made, termination advised and accepted, and the fetus was studied by a number of techniques.

\section{Case Report}

The family first came to attention when the index case (III.2, see Fig. 1) was found at the age of 6 months to be developing slowly and to have a lump on her back. This child, a girl, was the first-born of non-consanguineous parents, though the mother had had a previous normal daughter by a different father. The diagnosis of Hurler's syndrome was made and at the age of one year she was further investigated in the Department of Paediatrics, University of Leeds. At that time she was obese, had a lumbar kyphosis, was unable to sit up but could

\footnotetext{
Received 7 December 1972

* Present address: Institute of Genetics, Church Street, Glasgow W1.

† Present address: Department of Biochemistry, Baylor College of Medicine, Texas Medical Center, Houston, Texas 77025, USA.
}

support her head, had plagiocephaly, clouding of the corneae, and the typical facial appearance of Hurler's syndrome (Fig. 2). Her liver was enlarged and the spleen palpable. Radiology showed the typical hooked vertebrae of Hurler's syndrome in the upper lumbar region (Fig. 3). Twenty-four urinary hexosamine was $4.6 \mathrm{mg}$ (normal range $1-3 \mathrm{mg}$ ).

The mother (II.3) was seen for genetic counselling on 1 February 1972 when it transpired that she was again pregnant, the date of the last menstrual period being in some doubt. On referral for obstetric opinion, it was

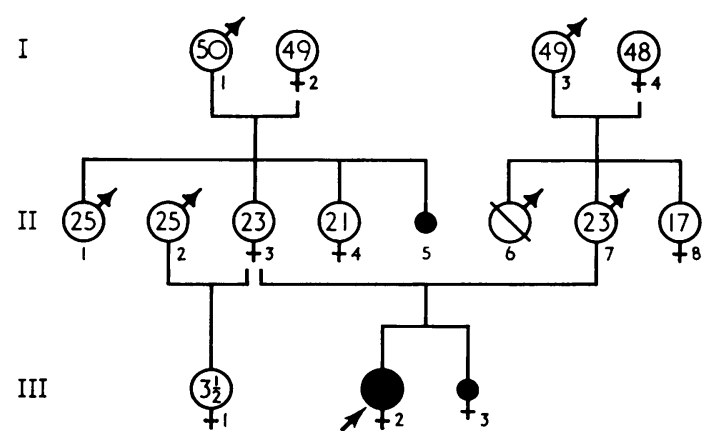

Fig. 1. Pedigree of the family in the present study. The numerals indicate the age at time of study. 


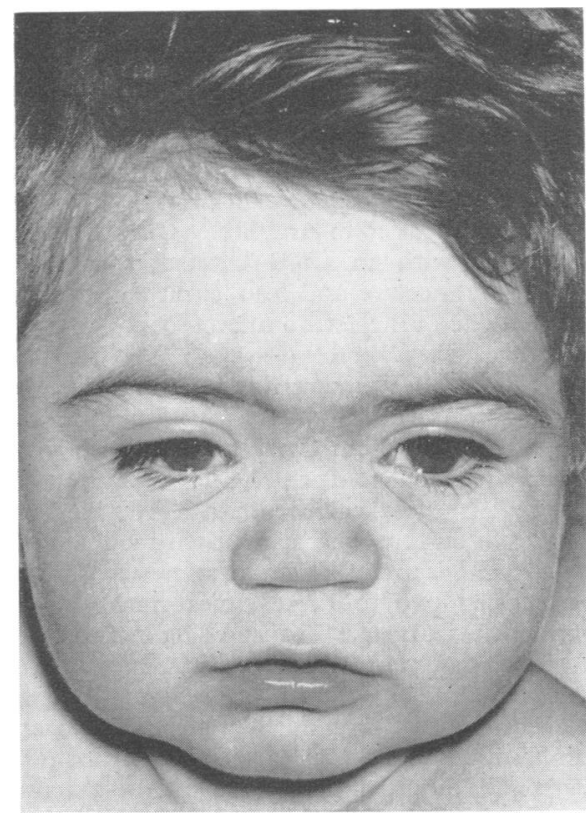

FIG. 2. Facial appearance of index patient (III.2).

found that fundal height was compatible with 14-16 weeks' gestation, and it was decided to carry out an amniocentesis at the earliest opportunity.

This sample was obtained and, after centrifugation, the cells were retained for culture and the cell-free liquor subjected to direct assay of glycosaminoglycan content. As a result of this latter investigation it was decided to advise termination of the pregnancy by hysterotomy, and the whole fetus thus became available for study at what was probably about the 18 th week of gestation. Immediately before the hysterotomy a second sample of amniotic liquor was withdrawn to provide material for a sequential study of its glycosaminoglycans. Immediately after delivery of the fetus samples of liver, spleen, cerebral tissue, and cerebellum were fixed in glutaraldehyde for electron microscopy, while the unfixed portions of these organs were frozen for eventual chemical investigation. A portion of skin was cleaned with surgical spirit, exercised, and placed in sterile TC199 for fibroblast culture.

\section{Methods}

Analysis of Glycosaminoglycans. The cell-free amniotic fluid was dialysed in Visking tubing, previously heated at $95^{\circ} \mathrm{C}$ to reduce its porosity, for 24 hours against 1 litre of water at $4^{\circ} \mathrm{C}$, re-centrifuged, and polyanions precipitated from the clarified supernatant solution by dropwise addition of aqueous 9-aminoacridine hydrochloride (saturated at $60^{\circ} \mathrm{C}$ ). After standing overnight at $4^{\circ} \mathrm{C}$ the precipitate was collected by centrifugation and the glycosaminoglycans converted to their sodium

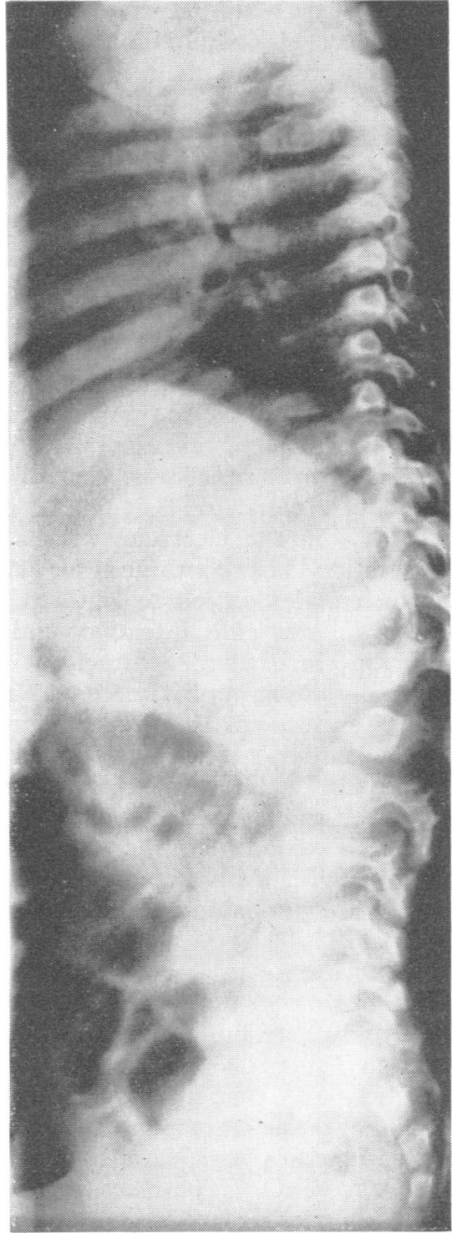

Fig. 3. Lateral radiograph of spine of index case, showing changes in the upper lumbar vertebral bodies typical of Hurler's syndrome.

salts by shaking with a suspension of Zeo-Karb $225\left(\mathrm{Na}^{+}\right.$ form) and $1 \mathrm{ml}$ of a sodium acetate buffer (Dean, Muir, and Ewins, 1971). The total uronic acid content of the sample was determined (Bitter and Muir, 1962), and the remainder of the material incubated at $37^{\circ} \mathrm{C}$ for 24 hours with 3000 turbidity reducing units of testicular hyaluronidase (EC 3.2.1.35). The undigested glycosaminoglycans were precipitated as above and re-converted to their sodium salts. The total uronic acid content of the remaining glycosaminoglycans (dermatan and heparan sulphates) was then re-determined.

Glycosaminoglycans were isolated from fetal liver by extraction with $0 \cdot 2 \mathrm{M}$ sodium acetate, $p \mathrm{H} 6 \cdot 8$, and the proportions of heparan, dermatan, and chondroitin sulphates determined as described by Dean et al (1971). Gel chromatography of a $2 \mathrm{mg}$ sample of glycosaminoglycans isolated from the liver was carried out on a 
column of Sephadex G-200 (12 $\mathrm{mm} \times 550 \mathrm{~mm}$ ) packed and eluted with $0.2 \mathrm{M}$ sodium acetate. Fractions of $0.85 \mathrm{ml}$ were collected and their uronic acid contents determined.

Tissue Glycosidases. $0.5 \mathrm{~g}$ samples of both liver and cerebral tissue from the fetus under investigation and from two age-matched control fetuses which had been aborted for other reasons, were homogenized in $1.5 \mathrm{ml}$ of iced distilled water on a Silverson laboratory mixer with micro head. The homogenate was then centrifuged at $2200 \mathrm{~g}$ for $30 \mathrm{~min}$ at $4^{\circ} \mathrm{C}$, the supernatant solution being retained undiluted for electrophoresis and diluted with two volumes of $0 \cdot 15 \mathrm{M}$ sodium citrate/phosphate buffer, $p \mathrm{H} 4.5$, for direct enzyme assays.

Starch gel electrophoresis was carried out using sodium phosphate buffers, $p \mathrm{H} 7.0,0.01 \mathrm{M}$ in the $11 \%$ gel bed and $0 \cdot 1 \mathrm{M}$ in the electrode vessels and paper bridges. Separation was continued for 17 hours at $2.5 \mathrm{~V} / \mathrm{cm}$ between plates cooled to $2^{\circ} \mathrm{C}$, at the end of which time the gel was split into two, and the upper and lower sections incubated separately at $37^{\circ} \mathrm{C}$ with paper overlays containing approximately $10 \mathrm{ml}$ of $0.1 \%$ 4-methylumbelliferyl $\alpha$ - or $\beta$-D-galactopyranoside in citrate/phosphate buffer, $p H 4 \cdot 8$, for 60 minutes. The gels were then made alkaline with strong ammonia solution, which allowed the regions of enzyme activity to be visualized under a Woods lamp, free methylumbelliferone fluorescing with a blue colour. (For clarity of reproduction we are publishing the negative images of these photographs.)

The direct enzyme assays were carried out on the diluted extracts using 4-methylumbelliferyl esters in $0 \cdot 15 \mathrm{M}$ citrate/phosphate buffers according to the conditions as given in Table $\mathrm{I}$.

Each estimation was carried out in duplicate with mixtures of $50 \mu \mathrm{l}$ of tissue extract and $100 \mu \mathrm{l}$ of substrate buffer solution in small plastic sample tubes in an airblown incubator at $37^{\circ} \mathrm{C}$. The reactions were stopped with $100 \mu \mathrm{l}$ of $5 \%$ trichloroacetic acid and the fluorescence of the released 4-methylumbelliferone developed with $2.0 \mathrm{ml}$ of $0.3 \mathrm{M} \mathrm{NaOH} /$ glycine buffer, $p \mathrm{H} 10.6$, immediately before reading on a Farrand Ratio Fluorometer fitted with Wratten $18 \mathrm{~A}$ excitation and $2 \mathrm{~A}$ emis- sion filters. These conditions had previously been shown to give reproducible and linear results.

Electron Microscopy. $1 \mathrm{~mm}$ cubes of liver, spleen, cerebrum, and cerebellum were fixed in 5\% glutaraldehyde in cacodylate sucrose buffer, $p \mathrm{H} 7 \cdot 2$, postfixed in $1 \%$ veronal acetate buffered osmic acid, dehydrated in ethanol, and embedded in Araldite. Ultra-thin sections were obtained with an LKB Ultratone, stained with aqueous uranyl acetate and lead citrate, and examined with an AEL EM 6B electron microscope.

Cell Culture. The centrifuged amniotic cells were re-suspended in $2.0 \mathrm{ml}$ of fetal calf serum, divided evenly between two $5 \mathrm{~cm}$ Carrel flasks, gassed with $5 \%$ $\mathrm{CO}_{2}$ in air, and incubated at $37^{\circ} \mathrm{C}$ for 4 hours. Thereafter $1 \mathrm{ml}$ of $10 \%$ fetal calf serum in RPMI medium was added to each culture which was then incubated for 10 days at $37^{\circ} \mathrm{C}$ without further interference. The cells were examined two to three times weekly and subcultured when necessary, feeding being maintained with $10 \%$ fetal calf serum in RPMI medium.

The fetal skin biopsy was cut into small fragments, secured in Carrel flasks by chicken plasma clots, and fed with medium containing $20 \%$ fetal calf serum in Minimal Eagle's Medium supplemented with L-glutamine at a final concentration of $0.25 \mathrm{mg} / \mathrm{ml}$. Within two weeks there was sufficient cell growth around the explants to permit trypsinization of the monolayer and the establishment of subcultures in $2 \mathrm{oz}$ soft glass medical bottles using $10 \%$ fetal calf serum in Minimal Eagle's Medium.

These subcultures were further sub-divided until four $2 \mathrm{oz}$ bottles were obtained. Two days after this final transfer, in which each bottle received an equal aliquot of cell suspension, the medium was replaced with the same mixture as before but containing isotopically labelled inorganic sulphate $\left({ }^{35} \mathrm{SO}_{4}\right)$ at a concentration of about $10 \mu \mathrm{Ci} / \mathrm{ml}$. This was left in contact with the cells for one week, after which the cells were washed three times with sterile Hank's A balanced salt solution and then fed with Minimal Eagle's Medium supplemented with either pooled human serum or new born calf serum in $30 \%$ mixture and buffered with $0 \cdot 5 \mathrm{M}$ HEPES, $p \mathrm{H} 7 \cdot 0$. One bottle was harvested directly. Twenty-four hours later

TABLE I

\begin{tabular}{|c|c|c|c|c|c|c|c|}
\hline & 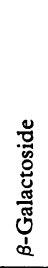 & 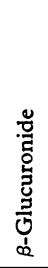 & 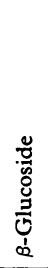 & 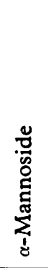 & 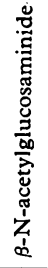 & 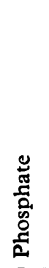 & 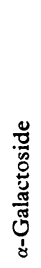 \\
\hline $\begin{array}{l}\text { Concentration }(\mathrm{mg} / \mathrm{ml}) \\
p \mathrm{H} \text { of buffer } \\
\text { Incubation time }(\mathrm{min})\end{array}$ & $\begin{array}{l}0 \cdot 5 \\
4 \cdot 5 \\
30\end{array}$ & $\begin{array}{l}1 \cdot 0 \\
4 \cdot 8 \\
30\end{array}$ & $\begin{array}{l}2 \cdot 0 \\
4 \cdot 8 \\
60\end{array}$ & $\begin{array}{l}1 \cdot 0 \\
4 \cdot 8 \\
30\end{array}$ & $\begin{array}{l}0 \cdot 5 \\
4 \cdot 5 \\
15\end{array}$ & $\begin{array}{l}1 \cdot 0 \\
4 \cdot 8 \\
15\end{array}$ & $\begin{array}{l}1 \cdot 0 \\
4 \cdot 8 \\
30\end{array}$ \\
\hline
\end{tabular}


the medium was decanted from the remaining cultures and the cells again washed with Hank's A solution several times before being digested in situ with $2 \mathrm{ml}$ of NCS solubilizer (Amersham Searle) for two hours at $60^{\circ} \mathrm{C}$. The resultant solution was mixed with $20 \mathrm{ml}$ of $0.5 \%$ BBOT in 4:1 toluene methanol. Aliquots $(400 \mu \mathrm{l})$ of the decanted medium from each bottle were dried onto strips of Whatman No. 1 filter paper and immersed in $0.5 \%$ BBOT in toluene in scintillation vials. Both types of sample were counted in a Packard scintillation counter.

\section{Results and Discussion}

Using phenyl- $\alpha$-L-iduronide as substrate, Bach et al (1972) and Matalon and Dorfman (1972) have recently discovered independently that the basic enzymic lesion in Hurler's syndrome is a defect in lysosomal $\alpha$-L-iduronidase (see also McKusick et al, 1972). This hydrolytic enzyme plays a major part in the degradation of dermatan sulphate, a glycosaminoglycan whose main chain repeating disaccharide unit consists of $\beta$-galactosaminyl- $\alpha$-L-iduronic acid. Removal of terminal non-reducing iduronic acid residues is normally carried out by $\alpha$-L-iduronidase, and in the absence of this enzyme further attack on the chain by exo-glycosidases is impossible. Patients with Hurler's syndrome accumulate a number of different storage products in different tissues-predominantly low molecular weight dermatan and heparan sulphates in the liver (Knecht $e t$ al, 1967), materials which are also found in excess in the urine of these cases, and a range of gangliosides in the central nervous system (Ledeen et al, 1965). While there can now be little doubt that the lack of iduronidase is the causative lesion, a number of other enzymic disturbances have been discovered in tissues and cell cultures from these children, the most remarkable being the great diminution in $\beta$-galactosidase $\mathrm{B}$ activity in the liver (Öckerman and Hultberg, 1968; van Hoof and Hers, 1968/1969) and other tissues (MacBrinn et al, 1969). It seems reasonable to postulate that the accumulation of substance other than dermatan sulphate may be due to these secondary enzyme changes, which may in turn be due to the high levels of this glycosaminoglycan altering the intralysosomal milieu.

At the time that this investigation was undertaken the basic defect had not been described in full, and it was necessary to use detection systems acting on the secondary changes to attempt to define the genotype of the unborn child. Two main approaches could be made to this problem-one described by Matalon et al (1970) consisted in a direct assay of the glycosaminoglycans of the liquor amnii, the other involving observation of the metabolism of sulphated macromolecules in cells cultured from the fetus.

One might expect that the liquor amnii of an affected fetus should always contain an excess of dermatan sulphate, as was reported by Matalon et al (1970) and confirmed in this case, since the metabolic error is expressed in many cases even before the birth of the child. Umbilical hernias, indicative of some connective tissue disturbance, are very common in affected neonates (Leroy and Crocker, 1966). Unfortunately, not only does the normal level of total glycosaminoglycans vary with the advance of pregnancy, but also in a disturbing number of cases the liquor has appeared to be normal and the resulting child found to be abnormal after being carried to term and delivered (Brock et al, 1971; Matalon et al, 1972). The reasons for these false negative results are not understood, but we may postulate either that the low molecular weight glycosaminoglycans can pass the placental barrier and be degraded by maternal tissues, or that maternal iduronidase may enter the fetus and prevent the accumulation of dermatan sulphate. The inconsistencies between different cases may depend upon one of many factors, the genetic constitutions of the fetus and the mother, the exact nature of the enzymic deficiency, or mechanical factors such as transplacental haemorrhage infusing the fetus with maternal cells. No figures appear to have been published on the relative frequency of positive and negative results of these assays in cases where the fetus had Hurler's syndrome.

In our case the uronic acid content of the amniotic fluid was $20.5 \mu \mathrm{g} / \mathrm{ml}$, and since glycosaminoglycans normally contain some $30 \%$ by weight of uronic acid (Olsson, 1969; Dean et al, 1971) this value corresponded to a glycosaminoglycan content of about $60 \mu \mathrm{g} / \mathrm{ml}$. Of this total $78 \%$ was resistant to digestion with hyaluronidase, ie, consisted of dermatan and heparan sulphates, the remainder consisted of hyaluronic acid together with the chondroitin sulphates. This high proportion of resistant glycosaminoglycans corresponded closely with the report of Matalon et al (1970) of findings on an affected fetus, and was considered to be adequate evidence to advise termination of the pregnancy. These biochemical assays required some 10 days for completion, the results being available considerably earlier than could be achieved by the study of cultured amniotic cells.

Much of the interest of this case arises from the examination of the abortus. We have been able to show that the liver and other tissues presented appearances analogous to those found in affected children at considerably later stages of the disease. 
148 Crawfurd, Dean, Hunt, Johnson, MacDonald, Muir, E. A. Payling Wright, and C. R. Payling Wright

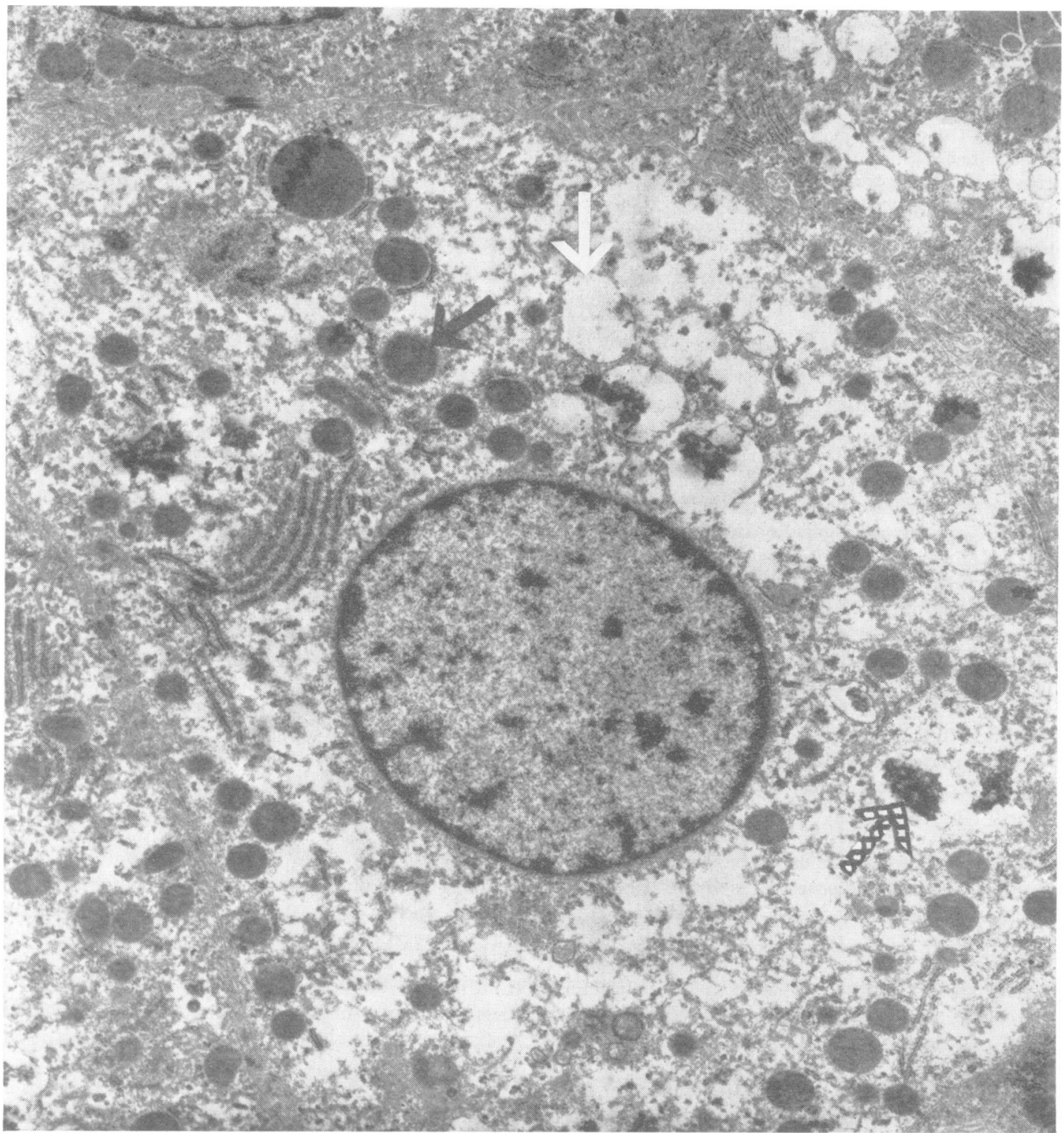

FIG. 4

FIGs. 4 and 5. Electron micrographs of liver from abortus showing numerous electron translucent lysosomal vacuoles in hepatocytes. Some of the lysosomes contain clusters of amorphous osmiophilic material Magnification: Fig. 4 black arrows indicate normal lysosomes, the white arrow translucent lysosomal vacuoles, and the hatched arrows osmiophilic inclusions.

The composition of the soluble glycosaminoglycans of the fetal liver was found to be: chondroitin sulphate $8 \cdot 8 \%$, dermatan sulphate $28.8 \%$, and heparan sulphate $62 \cdot 4 \%$. These compounds showed evidence of having undergone considerable degradation since the bulk of the material was eluted from Sephadex G-200 at a position closely corresponding to the total bed volume of the gel. This finding would indicate a molecular weight of $\mathbb{D}$ about 5000, which is within the range encountered in the tissues and urine of patients with Hurler's syndrome (Dean et al, 1971). 


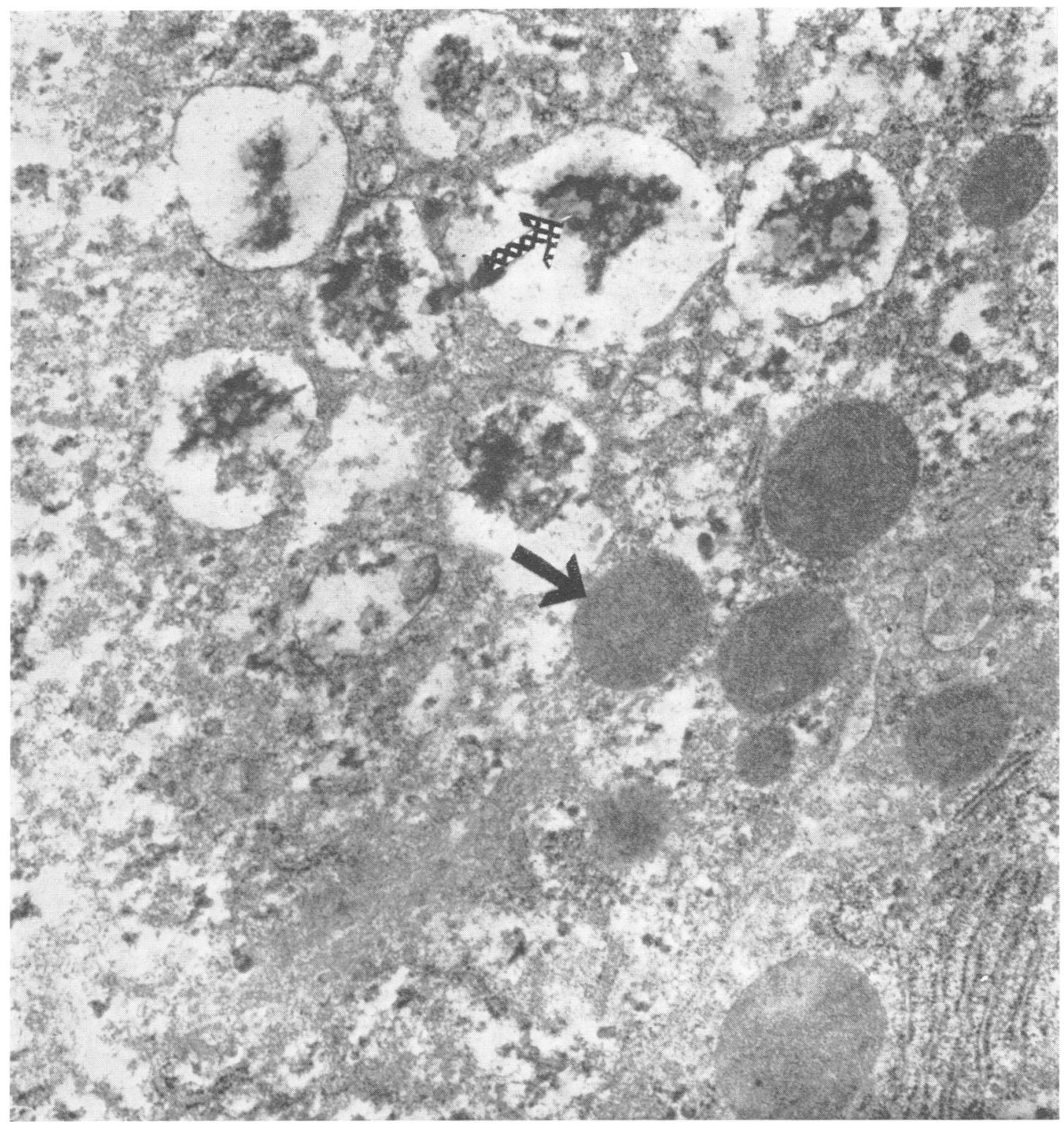

FIG. 5

Examination of the electron micrographs of the liver (Figs. 4 and 5) show a definite likeness to the lysosomal changes described postnatally by van Hoof and Hers (1964) and Callahan and Lorincz (1966); electron translucent vacuoles containing a few osmiophilic inclusions being present in almost every cell. The early development of these storage depots argues for their primary role in the develop- ment of the disease, much as the demonstration of multi-lamellar bodies in the central nervous system of early fetuses with $\mathrm{GM}_{2}$ gangliosidosis demonstrates the importance of $\mathrm{N}$-acetyl- $\beta$-hexosaminidase $A$ in the aetiology of Tay-Sachs disease (Schneck et al, 1970). It is notable that in this 18-week fetus the cells of the central nervous system showed no sign of inclusions (Fig. 6), either electron 


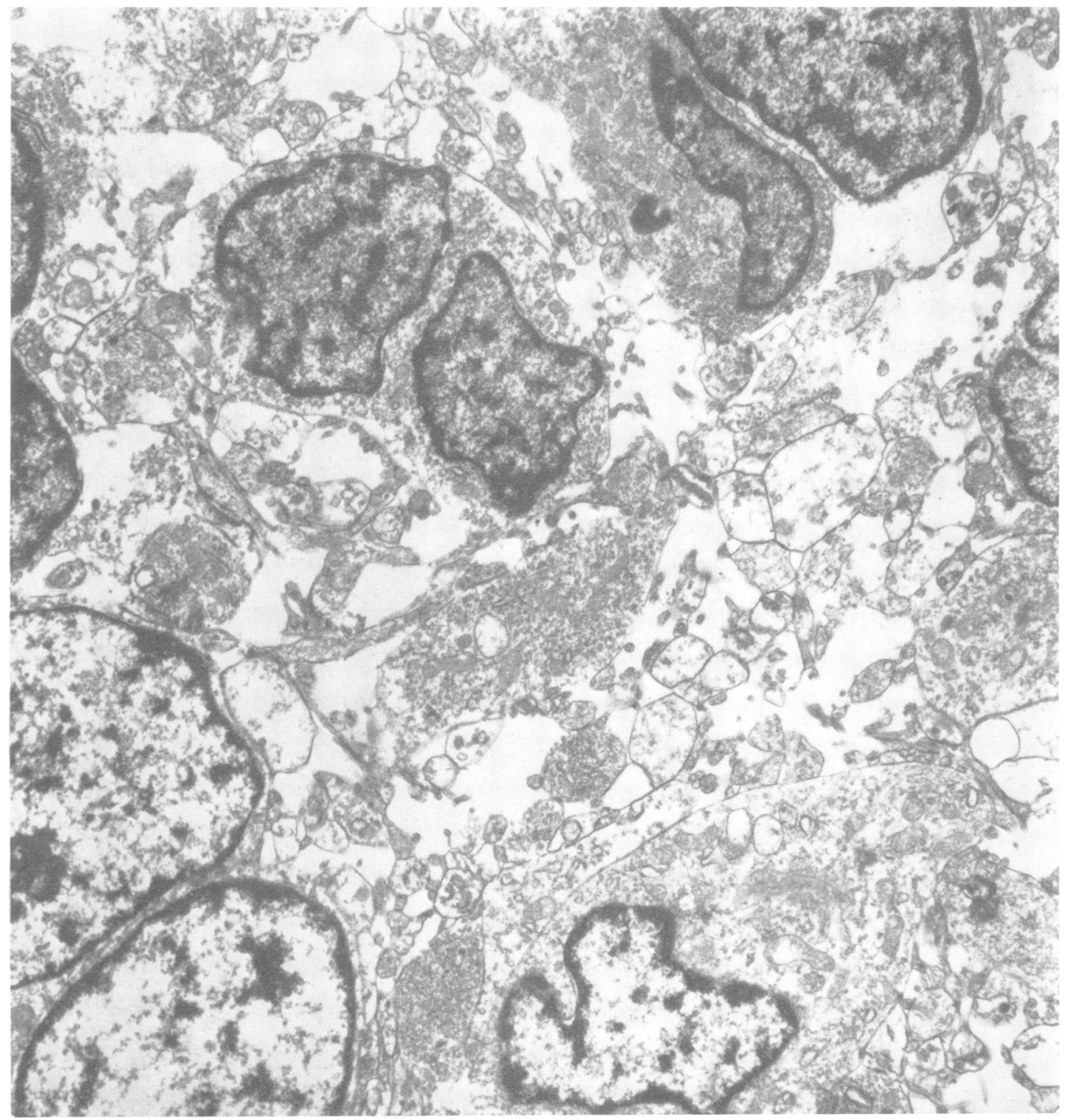

FIG. 6. Electron micrograph of cerebellar neurones. There is no evidence of excessive vacuolation here or elsewhere in the central nervous system. Magnification: $\times 5000$.

translucent or of the Zebra body formation (Aleu, Terry, and Zellweger, 1965). This again confirms the subsidiary nature of the ganglioside accumulation of this disease, already known to be non-specific in pattern with increases in $\mathrm{GM}_{1}, \mathrm{GM}_{2}$, and $\mathrm{GM}_{3}$. The glycosidases of both liver and cerebrum were however somewhat disturbed, though the changes in the former tissues were not so great as reported by other workers on material from older children with Hurler's syndrome. Starch gel electrophoresis of the liver extracts (Fig. 7) show anomalies of both $\alpha$ and $\beta$-galactosidases, the slow migrating bands being in each case markedly reduced compared with the normal age-matched control samples. 

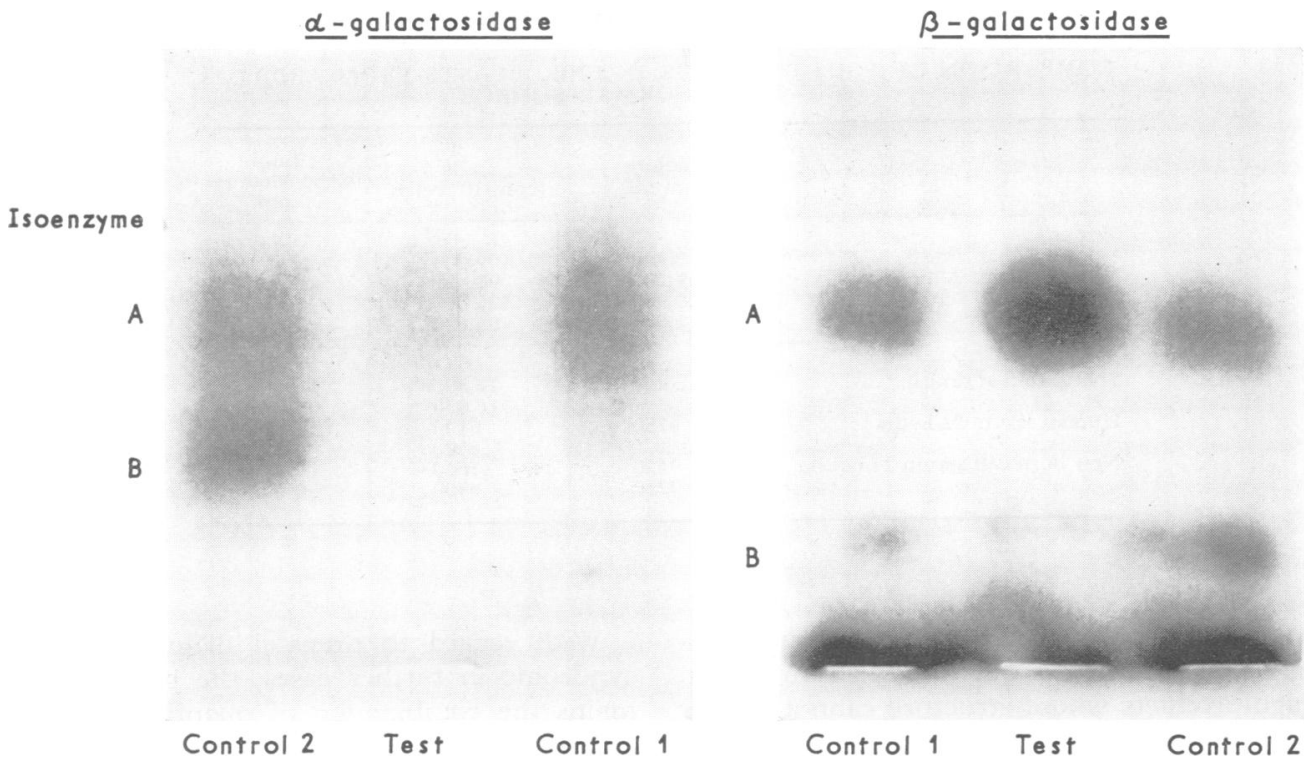

FIG. 7. Starch gel electrophoresis of extracts of fetal liver, showing relative deficiencies of B-isoenzymes of both $\alpha$ - and $\beta$-galactosidases. The negative images of fluorescence of released 4-methyl-umbelliferone are shown here. (Courtesy of Elizabeth Gardiner.)

Results of the assay of a range of lysosomal enzymes on the crude extracts of both liver and brain are given in Table II, and are expressed as nanoMoles of substrate cleaved/hour/mg wet weight of tissue. Both tissues show relative deficiencies of both $\alpha$ - and $\beta$-galactosidases with absolute increases in most of the other enzymes examined. These abnormalities although evident are not nearly so striking as the changes described in the liver of affected children aged one year and over. This intermediate reduction of the galactosidases would be not unexpected if the observed level of these enzymes were subject to modification by the accumulation of intralysosomal glycosaminoglycans. Such tertiary enzyme defects would explain not only the presence of diminished $\beta$-galactosidase levels

TABLE II

ACTIVITIES OF ACID HYDROLYTIC ENZYMES* IN EXTRACTS OF FETAL LIVER AND CEREBRAL TISSUES

\begin{tabular}{|c|c|c|c|c|c|c|c|}
\hline & 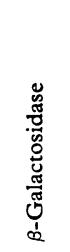 & 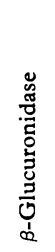 & 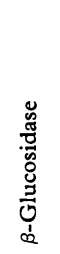 & 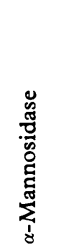 & 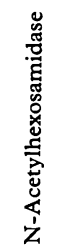 & 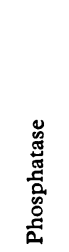 & 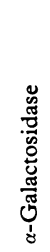 \\
\hline $\begin{array}{l}\text { Liver } \\
\text { Control } 1 \\
\text { Control } 2 \\
\text { Test } \\
\text { Test/control }\end{array}$ & $\begin{array}{r}1600 \\
1800 \\
1500 \\
0.9\end{array}$ & $\begin{array}{r}300 \\
310 \\
800 \\
2 \cdot 6\end{array}$ & $\begin{array}{r}200 \\
200 \\
440 \\
2 \cdot 2\end{array}$ & $\begin{array}{r}120 \\
170 \\
250 \\
1 \cdot 7\end{array}$ & $\begin{array}{r}3900 \\
4600 \\
5800 \\
1 \cdot 4\end{array}$ & $\begin{array}{r}1700 \\
2300 \\
2600 \\
1 \cdot 3\end{array}$ & $\begin{array}{r}150 \\
220 \\
110 \\
0.6\end{array}$ \\
\hline $\begin{array}{l}\text { Brain } \\
\text { Control 1 } \\
\text { Control 2 } \\
\text { Test } \\
\text { Test/control }\end{array}$ & $\begin{array}{r}160 \\
160 \\
50 \\
0 \cdot 3\end{array}$ & $\begin{array}{r}16 \\
23 \\
19 \\
1 \cdot 0\end{array}$ & $\begin{array}{c}14 \\
16 \\
50 \\
3 \cdot 3\end{array}$ & $\begin{array}{r}74 \\
80 \\
82 \\
1.0\end{array}$ & $\begin{array}{r}720 \\
870 \\
1050 \\
1.3\end{array}$ & $\begin{array}{r}675 \\
645 \\
1640 \\
2.5\end{array}$ & $\begin{array}{r}16 \\
22 \\
9 \\
0.5\end{array}$ \\
\hline
\end{tabular}

* Expressed in $\mathrm{n}$-Mole substrate cleaved $/ \mathrm{hr} / \mathrm{mg}$ wet weight of tissue. 
TABLE III

COMPARISON OF ${ }^{35} \mathrm{SO}_{4}$ TURNOVER IN FIBROBLASTS FROM ABORTUS AND FROM NORMAL SOURCE

\begin{tabular}{l|c|c|c}
\hline & $\begin{array}{c}\text { Medium } \\
(\mathrm{cpm} / \mathrm{ml})\end{array}$ & $\begin{array}{c}\text { Cells } \\
\left(\mathrm{cpm} / 10^{5} \text { cells }\right)\end{array}$ & $\begin{array}{c}\text { Ratio } \\
\text { Cells/Medium } \\
\text { (cpm) }\end{array}$ \\
\hline Test cells & Not counted & 109,000 & \\
Solubilized at time 0 & 39,200 & 90,452 & $2 \cdot 31$ \\
Human serum 24 hours & 20,980 & 125,000 & $5 \cdot 96$ \\
New born calf serum 24 hours & 11,660 & 83,600 & $7 \cdot 12$ \\
\hline Normal cells & & & \\
Solubilized at time 0 & Not counted & 12,000 & \\
& & 16,000 & $1 \cdot 28$ \\
Human serum 24 hours & 4750 & 6100 & $0 \cdot 61$ \\
New born calf serum 24 hours & 10,620 & 7600 & $0 \cdot 84$ \\
& 9120 & 6400 & $0 \cdot 69$ \\
\hline
\end{tabular}

in a number of genetically distinct mucopolysaccharidoses, but also the quaternary accumulation of storage products whose structure cannot readily be related to the primary biochemical lesion, such as the gangliosides of brain and liver.

As a final confirmation of the genetic status of this abortus, the ${ }^{35} \mathrm{SO}_{4}$ turnover in cells cultured from the fetal skin was compared with that of normal dermal fibroblasts. Neufeld and her collaborators (Neufeld and Fratantoni, 1970) have, in a series of papers, built up much of our understanding of mucopolysaccharidoses. At the outset they showed that cells cultured from patients with these disorders did not synthesize sulphated glycosaminoglycans at an accelerated rate, but rather that loss of ${ }^{35} \mathrm{SO}_{4}$ from the cellular pool proceeded too slowly. Their major achievement was to show that this metabolic error could be corrected by humoral factors from normal individuals or their cells, or from patients with other types of mucopolysaccharidosis. These corrective factors prevent the pathological accumulation of sulphated material in the abnormal cells or lead to their rapid degradation and release from the intracellular stores once they have been built up. In several instances these factors have proved to be identical with the lysosomal enzyme deficiency specific to the condition (McKusick et al, 1972).

In these observations we have shown (Table III), that the cells from the abortus accumulate excessive quantities of labelled sulphate and that the storage products are released rather more quickly in the presence of human serum, which contains some Hurler corrective factor, than in calf serum, which has no correcting capacity. This behaviour agrees well with the observations of other workers on cells from patients with Hurler's syndrome.
With regard to prenatal diagnosis of Hurler's syndrome in further cases, the best approach remains the combination of quantitative and qualitative determination of the glycosaminoglycans of the liquor amnii, and the sulphate turnover of cultured amniotic cells. It is to be hoped, however, that before long it will be possible to assay $\alpha-\mathrm{L}$ iduronidase directly in amniotic cells, either by direct harvest or after short periods of cultivation. By either approach, the development of 4-methylumbelliferyl substrate would appear to offer the best prospect of detecting a very low level of enzyme activity. It still seems prudent to retain a cautious approach in counselling patients who are not pregnant as to the reliability of early prenatal diagnosis, but most affected fetuses should be detected by the 20th week of gestation when amniocentesis is undertaken at the 14th-15th week. There can be no doubt, however, that should the amniotic culture fail to give an unequivocal normal result termination should be strongly advised, since the glycosaminoglycan assay gives too many false negative results.

We are grateful to Dr C. S. Livingstone who made the original diagnosis in the index case; and to Professor R. W. Smithells and Dr J. M. H. Buckler of the Department of Paediatrics, University of Leeds, for permission to report their findings on the index case and to the latter also for his helpful comments; and to $\mathrm{Mr} \mathrm{H}$. N. Macdonald for the first amniocentesis. We should like to thank the Medical Research Council for a grant to M.F.D.

\section{REFERENCES}

Aleu, F. P., Terry, R. D., and Zellweger, H (1965). Electron microscopy of two cerebral biopsies in gargoylism. fournal of Neuropathy and Experimental Neurology, 24, 304-317.

Bach, G., Friedman, R., Weissmann, B., and Neufeld, E. F. (1972) The defect in the Hurler and Scheie syndromes: Deficiency of $\alpha \mathbf{L}$ iduronidase. Proceedings of the National Academy of Sciences, 69, 2048-2051. 
Bitter, T. and Muir, H. (1962). A modified uronic acid carbazole reaction. Analytical Biochemistry, 4, 330-334.

Brock, D. J. H., Gordon, H., Seligman, S., and Lobo, E. de H. (1971). Antenatal detection of Hurler's syndrome. Lancet, 2, 1324-1325.

Callahan, W. P. and Lorincz, A. E. (1966). Hepatic ultrastructure in the Hurler syndrome. American fournal of Pathology, 48, 277-298.

Dean, M. F., Muir, H., and Ewins, R. J. F. (1971). Hurler's, Hunter's, and Morquio's syndromes. A biochemical study in the light of current views of the underlying defects. Biochemical fournal, 123, 883-894.

Fratantoni, J. C., Neufeld, E. F., Uhlendorf, B. W., and Jacobson, C. B. (1969). Intrauterine diagnosis of the Hurler and Hunter syndromes. New England fournal of Medicine, 280, 686-688.

Knecht, J., Cifonelli, J. A., and Dorfman, A. (1967). Structural studies on heparitin sulphate of normal and Hurler tissues. fournal of Biological Chemistry, 242, 4652-4661.

Ledeen, R., Salsman, K., Gonatas, J., and Taghavy, A. (1965). Structure comparison of the major monosialogangliosides from brains of normal human, gargoylism and late infantile systemic lipidosis. Fournal of Neuropathology and Experimental Neurology, 24, 341-351.

Leroy, J. G. and Croker, A. C. (1966). Clinical definition of the Hurler-Hunter phenotypes. A review of 50 patients. American fournal of Diseases of Children, 112, 518-530.

MacBrinn, M., Okada, S., Woollacott, M., Patel, V., Ho, M.-W., Tappel, A. L., and O'Brien, J. S. (1969). Beta-galactosidase deficiency in the Hurler syndrome. New England fournal of Medicine, 281, 338-343.

McKusick, V. A., Howell, R. R., Hussels, I. E., Neufeld, E. F., and Stevenson, R. E. (1972). Allelism, non-allelism, and genetic compounds among the mucopolysaccharidoses. Lancet, 1, 993996.

Matalon, R. and Dorfman, A. (1972). Hurler's syndrome, an $\alpha$-Liduronidase deficiency. Biochemical and Biophysical Research Communications, 47, 959-963.

Matalon, R., Dorfman, A., and Nadler, H. L. (1972). A chemical method for the antenatal diagnosis of mucopolysaccharidoses. Lancet, 1, 798-799.

Matalon, R., Dorfman, A., Nadler, H. L., and Jacobson, C. B. (1970). A chemical method for the antenatal diagnosis of mucopolysaccharidoses. Lancet, 1, 83-84.

Milunsky, A., Littlefield, J. W., Kanfer, J. N., Kolodny, E. H., Shih, V. E., and Atkins, L. (1970). Pre-natal genetic diagnosis. New England fournal of Medicine, 283, 1370-1381, 1441-1447, 14981504.

Neufeld, E. F. and Fratantoni, J. C. (1970). Inborn errors of mucopolysaccharide metabolism. Science, 169, 141-146.

Ockerman, P. A. and Hultberg, B. (1968). Fractionation of 4methylumbelliferyl- $\beta$-galactosidase activities in liver in gargoylism. Scandinavian fournal of Clinical Laboratory Investigation, 22, 199202.

Olsson, I. (1969). Chondroitin sulfate proteoglycan of human leukocytes. Biochimica et Biophysica Acta, 177, 241-249.

Schneck, L., Valentini, C., Amsterdam, D., Friedland, J., Adachi, M., and Volk, B. W. (1970). Prenatal diagnosis of Tay-Sachs disease. Lancet, 1, 582-583.

Van Hoof, F. and Hers, H. G. (1964). L'ultrastructure des cellules hépatiques dans la maladie de Hurler (gargoylisme). Comptes Rendus Hebdomadaires des Séances de l'Académie des Sciences, 259, 1281-1283.

Van Hoof, F. and Hers, H. G. (1968/1969). The abnormalities of lysosomal enzymes in mucopolysaccharidoses. European fournal of Biochemistry, 7, 34-44. 